\title{
Partnership as meaningful tool of the material environment design formation in the context of education process
}

\author{
Jonas Jakaitis, Linas Krūgelis, Vilnius Gediminas technical university, Lithuania
}

\begin{abstract}
This paper explores the process of practical Industrial product design education peculiarities at Vilnius Gediminas Technical University, by examining it from Problem-Based Service-Learning (PBSL) perspectives. The author's viewpoint is developed from conceptual idea to prototype and used as a basis for debate about the following question: How well does design education prepare students for real practical activity? In fact, the historically dominant model in design education, which focuses mainly on vocational skills without real practical adaptation, is investigated. On the one hand, the author observes that this model is still not suitable to provide designers with the critical skills and knowledge required for practical-based projects. On the other hand, the author identifies that traditional teaching can result in a procedural, technical and cognitive limitation. Equilibrating design-based skills with real practical-based skills is an interesting challenge for Industrial Product Design teachers. Discussion around PBSL method issues will be introduced in the case study format and wider influence of real practical-based projects in industrial product design education. Additionally, we could study from similar case studies of vocational disciplines (such as Architecture or Design) that are moving towards a real practical-based approach to their education.
\end{abstract}

Keywords: material environment design, Problem-Based Service-Learning, creativity studies

\author{
Introduction \\ “... good societies produced good people and good people \\ produced good design."
}

\section{Augustus Pugin}

Using the innovative education methods that are being implemented in Lithuanian higher education and study programmes, such as Problem-Based Service-Learning (PBSL), is inevitable if education environment is to be brought closer to solving of the real problems. The aspects of PBSL education in the study process are discussed in the context of theoretical and practical interactions and problem solving in industrial design taking place in VGTU in cooperation with the social partners. The purpose of this paper is to review the practical peculiarities of the education in the applied material environment design formation, exploring them as well as considering the matter from the point of view of applicability of Problem-Based Service-Learning (PBSL) method. The problems of PBSL method implementation is studied in consideration of theory, literature, practical knowledge and analogue comparative analysis, survey and process monitoring methods. The analysis of practical aspects of partnerships involving the Problem-Based ServiceLearning reveals that in the education process the integrated conceptual methods for affinity diagramming of ideas allow students understanding, in an interaction with practical problem solving, the laws of harmonious coexistence of material entirety. The practical application of the PBSL method, well known in the Western countries, [1] demonstrates that this is a creative process of a complex nature which depends on many global and local social, cultural, historical and educational concept factors that determine the mutual benefit brought by an integrated cooperation of education and business. The application of this method is not only objectively inevitable but also necessary in order to train a more competitive free market 'player'. Undoubtedly, it is necessary in applying theoretical knowledge to link it to a creative education, operating in an interdisciplinary context of real challenges. The ability to liberate individual creative skills conferring them an applied nature becomes a challenge to all institutions involved in education, including universities. Modern universities face challenges in developing students' ability to apply knowledge in practice as well as in implementing their students' ideas, often of a futuristic nature. Participation in solving specific problems - from ideas to prototypes - in the context of formation of a changing material environment is paramount to students as a learning stimulating factor. Therefore, there is an increasing recognition among the academic community of the need for education oriented towards creative, targeted (means being valid for solving real problems - author's note) and smart thinking as this forms the basis of a creative society. 
Thus, a today's society based on creativity in many activity areas is called a 'smart' society and this is a priority objective of many countries' political decisions. On the contrary, if the society is not smart, it cannot be neither a civil society, nor a society actively participating in the formation of a safe and sustainable material environment. The priorities defined in the Lithuania's Progress Strategy 'Lithuania 2030' and the implementation of this Strategy are associated with the necessity of developing a smart society, in other words, the concept of a smart society is understood as encompassing not only knowledge and its creative management, but the concept is also generally associated to a systematic coherence in the information management and mentality culture, to society's skills as well as to its engagement (means participation in the creative processes - author's note) [2]. However, discussions are still under way on how to educate a creative person, recognise the valuable features of a creative result and maintain the engagement of the members of the creative society [3], since part of the creative manifestations of consciousness disappear due to the fact that they have not been recognized.

\section{The methodological foundations of the Problem- Based Service-Learning stem from post-modern culture origins}

Future specialists that will work in a macro architectural-urban environment and in a micro material environment (ME) not only need accumulating the knowledge acquired in the ordinary education process but also developing practical skills through creative implementation of this knowledge. In this paper the material environment (ME) is understood as the entirety of objects of anthropogenic activity and elements of natural environment, objects that constantly surround people and their components. The ME serves purpose and fulfills a decorative function, it includes stationary or movable objects as well as objects featuring not only a high aesthetic expression: household accessories, household items, architectural [4], urban engineering, recreational and other infrastructure objects, landscape architecture details, furniture, lighting ... and other details of the material entirety.

Humans are sensitive to the space, the forms of the surrounding environment, therefore the material environment is subject to social, functional, economic, environmental harmony, ergonomic, aesthetic, design and sustainability requirements. The surrounding ME affects the psychophysiological state of a person, highly influences the quality of everyday life and the primary focus of object formation is undoubtedly linked to the improvement of quality of life criteria. Experience gained in other countries demonstrates that PBSL education, based also on the result applicability methods, is viable and meaningful. A clear proof of it is the discourse on innovative and Problem-Based Service-Learning methods and tn applicability of results (using inclusive design principles - author's note). The PBSL method has been debated in various aspects in the scientific literature since the second half of the 20th century $[5 ; 6 ; 7 ; 8 ; 9]$. Nevertheless, the contemporary research on ways to implement meaningful learning in specific study programs such as Industrial Design (technology science - auth. note), Urbanism, Architecture, Formation of landscape material environment in urban areas, in association with design activities, is not very abundant in Lithuania. However, after 2011, when a discourse launched by the European Union at a political level [10] discussed the recommendations made by the Industrial Design Council, how to strengthen European innovation policy at different levels and how to develop a common vision making environmental design an integral part of pan-European innovation policy, the problem was especially actualized.

Following the world's experience, it is evident that for example the US interest in the PBSL method in higher education institutions increased in the late 20th century when American schools lost the public's confidence. It was aimed to establish universities as a tool for citizenship, enabling the most democratic approach to addressing real problems of society through cooperation and partnership [11]. The PBSL method was aimed at bringing teaching and learning closer to real life problems and solving them. The application of the method shows that this is a creative process of a complex nature, which depends on many global and local social, cultural, historical and teaching factors, which underpin mutual benefit in the science and business integrated cooperation. The current experience of using the PBSL method in the United States shows that teaching / learning focused on collaborating with public sector institutions, local communities, social partners and businesses is an effective basis for meaningful teaching/learning.

Discourse in the context of ontological values today is important in the context of the subject matter. Studies show that the most commonly used teaching is limited to theoretical knowledge, which is usually futile and difficult to apply in practice. Theoretical knowledge does not guarantee the right application of knowledge in real life situations. However, there is a lack of innovative creativity and motivation to do so. Students are well-versed in the 
knowledge that is most relevant to their needs, knowledge that is discussed in their environment with like-minded people. And most of what students learn theoretically does not seem to be personally important to them. [6]. Obviously, there is a need for innovations in the training / learning area to help students deliver meaningful, practically applicable learning. It can help in the most effective way to achieve the results of creative and meaningful, practical teaching and learning.

In this context, the relevance of the problem sed teaching method in part is revealed by the studies of the World Intellectual Property Organization (WIPO), which emphasize the need to develop partnerships in terms of solutions to practical problems and is one of the many, but the priority directions for the development of education. Studies discuss the cooperation between the WIPO and the State Patent Bureau of the Republic of Lithuania, as the state institutions are partly responsible for the creative activity and the formation of the material environment copyright policies, by awarding annual awards to the most creative Lithuanian developers of applied art and design [112]. However, the European Commission document [13] shows a lack of cooperation in the education sector. 2009 EU Parliaments document "Education and Training 2020" highlighted one of the most important tasks to emphasize the importance of increasing scientific innovation and entrepreneurship at all levels of education. In 2010, with a need to advance innovation and creativity in the field of development, the government approved the Lithuanian Innovation Strategy [14], whose vision is related to the strengthening of the Lithuanian economy and the practical application of education. The strategy addresses the development of high value-added products and the enhancement of service competitiveness on the global market. Obviously, the skills of adaptability must be developed by communicating, exchanging knowledge, and complexly addressing the aesthetic, economic or social coexistence problems of the material environment in urban spaces.

Lithuanian higher education development trends are improving, but the country still does not show a rapid development of innovations. From 2014, Lithuania has remained at the top of fifty, out of 127 world-ranked states, in terms of innovation development and has hit the relatively stable world ranking of countries together with Malta (26), Belgium (27), Spain (28), Italy (29), Portugal (31), Slovenia (32), Latvia (33), Slovakia (34), Bulgaria (36), Poland (38), Hungary (39), Lithuania (40) Croatia (41), Romania (42), Greece (44), Russian Federation (45), Montenegro (48) [15]. It can be

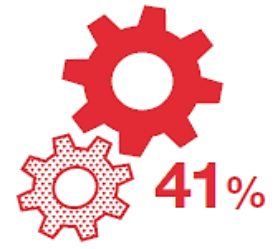

Workers with a design element to their work were $41 \%$ more productive than

Fig. 1. Using the principles of design of the material environment, the productivity of manufacturing enterprises increases by $41 \%$ compared to those who did not use that

Source: http://www.sumani2020.lt/ naujienos/70-ka-reiskia-investuoti-i-dizaina [accesed 10.04.2018].

assumed that the reason for this stagnation is the poor development of the partnership by using a design tool in the development of innovation. 2016 EC Innovation Barometer data reveals that $63 \%$ of Lithuanian companies in 2015 have not used design as an innovative solution tool, thus losing not only the momentum of the development of applied innovations, but also the growth of economic potential. (Fig. 1)

At either stage of the product development (product strategy development, analysis, concept or conceptual stylistics, design or prototype production and testing), neither applied design nor PBSL methods were sufficiently developed. Thus, the Lithuanian innovation development indicator is below the EU average, where almost half of all company design decisions are based on the principles of design thinking. Moreover, studies by the UK Design Council indicate that Lithuania, in terms of design, is one of the few European countries that has no design policy [16].

Regarding the application of the PBSL method in Lithuanian higher education institutions [9], the PBSL method, in conjunction with practical needs, allows students to deepen their practical knowledge and offer realistic solutions to problems. According to student surveys of the VGTU Design Department, about $90 \%$ respondents acknowledged that teaching/learning, using real problems, promotes a sense of responsibility, adaptation to local needs, develops the skills of communicating with communities or businesses and the ability to find the best solutions. Solutions that can be competitive on the market and are attractive to the public by their engineering solutions. Practice where problems of designing urban, engineering, technological or material environment are investigated often become realistic challenges for students in practical cognition and complex design objects. Practice when urban, engineering, technological or material environments problems are investigated 
often become students' practical knowledge challenges and complex design objects. Thus, the ability to solve real problems in a collaborative environment today is one of the most effective measures in order to develop practical skills.

The idea of a humanistic theorist [17] states that it is impossible to teach a person, we can only help him study creatively. This basically corresponds to the latest demands of Problem-Based Service-Learning ideas. And this is a fundamental part of the content of a good design in the material environment - to create the added value of the qualitative welfare of the material environment. The quality of life in the article is understood as defined by the World Health Organization (WHO) - as an individual's perception of their position in life in the context of the culture and value systems in which they live and in relation to their goals, expectations, standards and concerns. It is a broad ranging concept affected in a complex way by the person's physical health, psychological state, personal beliefs, social relationships and their relationship to salient features of their environment (World Health Organization). Thus, examination of the material environment coexistence, aesthetic harmonization is an important aspect of human coexistence and quality of life.

\section{Modern-day partnership oriented PBSL method applicability case studies}

The ability to solve problems and formulate applied ideas (to be creative) in an interdisciplinary environment is the primary focus of the PBSL education. Having ideas, as to being creatively and innovatively rich, integrating new information and innovations into the existing knowledge is the main task for human creativity [18]. In the creative process, not only are objects being developed, the environment of their material entirety, but also is formed the user of the objects, which finds a connection with people and society [19]. In other words, reflecting on the process of everyday things, the aesthetic, creative requirements are brought forward for the learner, helping to understand the environment and themselves in this context, to become aware of the nature-human-environment system, to formulate and coordinate rational and irrational ways of solving problem [20] in relation to the needs of a particular subject. The quality of the surrounding material environment in urban spaces is an essential purpose of the harmonious coexistence of people with the environment and a condition of a positive psychophysiological state. It is close to the learner or discouraging, well-known or foreign, perceived or repulsive as a dimension of harmonious cohabitation with the environment, in which the formation of local identity reflects the aspect of the creative adaptability of our activities. Under these circumstances and conditions, students of the Department of Design each year become accustomed to solving practical problems.

The PBSL education method was adopted by the author of this paper when working with the students at the Faculty of Environmental Engineering, later in the Institute of Architecture, later at the Department of Design. The methodological principles of the PBSL together with the problematic education method were developed by evaluating the experience of the application of PBSL when preparing the project Renewal of programs in the field of sustainable living environment study, using innovative learning methods to strengthen interdisciplinary interconnections and introducing the concept of sustainable development' [21]. In the project, the creative two-way (old and PBSL) dialectical search methods for the harmonization of interconnection were focused on highlighting education methods, although each constituent obviously has an independent purpose. In the context of the previously mentioned project, the author's study book [22] and later in the monograph [23], focuses on both the problematic education method and the PBSL method analysis. By applying them to the complex design of the city's spatial, landscape architectural and transport systems, the activity of designing the real estate environment was aimed at solving the applied tasks. In this way, the implementation of the study programs gradually formed a specific educational technique and the culture of communication between the academic community and the producers-practitioners. Investigating, for example, the reasons that led to the psychophysiological sensation of people in the surroundings of specific objects, the ways of improving the existing quality of the realm of the environment, are suggested for the continuous design studies future designers, prospective urbanists, manufacturing engineers, design engineers. Qualitative data in both cases was offered in a set of observational process, photo fixation, unstructured interviews, analysis of objects and analogues of objects and documents and literature. Summarizing the data, it is recommended as the result of the research to prepare a real prototype M1:1. Testing and improving it, in the event of success, as an intermediate result of the design mind-set, would continue at another stage in the formation of the material environment.

\section{Learning by doing - the foundation of the studies at the Department of Design}

The abundance of applicability and the endless field of today's problems allow students to study in detail the tasks of harmonizing various objects of 
household design (Fig. 2) or the urban material environment [24].

The choice of the object depended on the fact that the work manager proposed the design of the conditioning system, addressing the current issue of interdisciplinary. In consultation with 'UAB Amalva' engineers, producing already existing product the student was given an opportunity to study the compatibility of the principles of aesthetics, production engineering, functionality and production, and, in the final result, obtain a prototype very close to the real product. When designing and choosing a concept, the student preferred the minimalist, rigid form design adapted to the environment and other technical equipment. Objects of such style are usually eye-catching, but they do not tarnish or hamper the daily routine of a person.

In addition to the already mentioned PBSL method, some of the final thesis assignments were formulated by the VGTU Design Department. Based on the principle of informal partnership, a business entity, in this case, JSC Amalva, in cooperation with the Design department lecturer Donaldas Andziulis, formulated relevant topics for the activities of the chosen company and its needs. Considering the fact that the requirements for energy efficiency of modern residential buildings are constantly increasing, the integration of heating, ventilation and air conditioning systems in the interiors of buildings is becoming increasingly important. There is a need for aesthetical integration of this engineering utilitarian equipment and its management blocks into the architectural spaces. For this purpose, the diplomat student Sandra Mažeikaite has prepared the diploma work project "Glacier II" (led by D. Andziulis) for the design of the heating and ventilation cabinets. The PBSL method was developed by the student directly consulting with engineers of the company that delegated the assignment and using their technological production base for making the prototype. The problem of the project was defined not only by the delegated task, but also by the company's manufacturing capabilities. Despite these restrictive factors, a very successful result has been achieved, a functional, contemporary, minimalist design product has been designed. The prototype of a real-sized product fully met the requirements of the task.

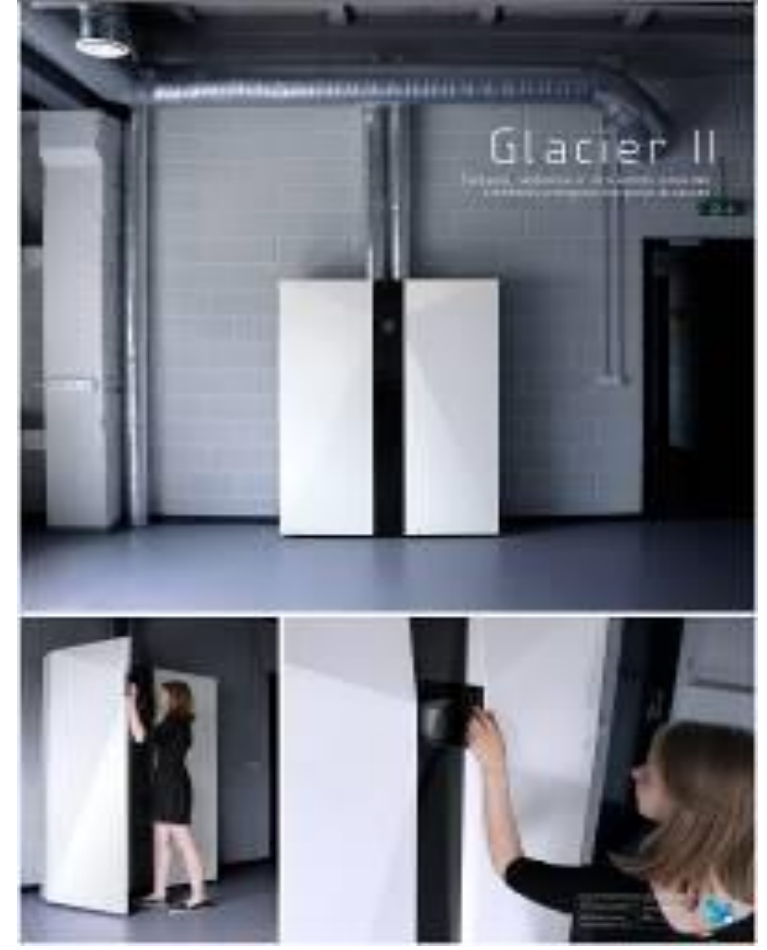

Fig. 2. S. Mažeikaite Bachelor's final work using the PBSL method. 'Design of the body of the heating, ventilation and air conditioning system. 2017' (head -

Lect. D.Andziulis, Consultant - Assistant Professor A.Chereška). Photo: the Department of Design's archive.

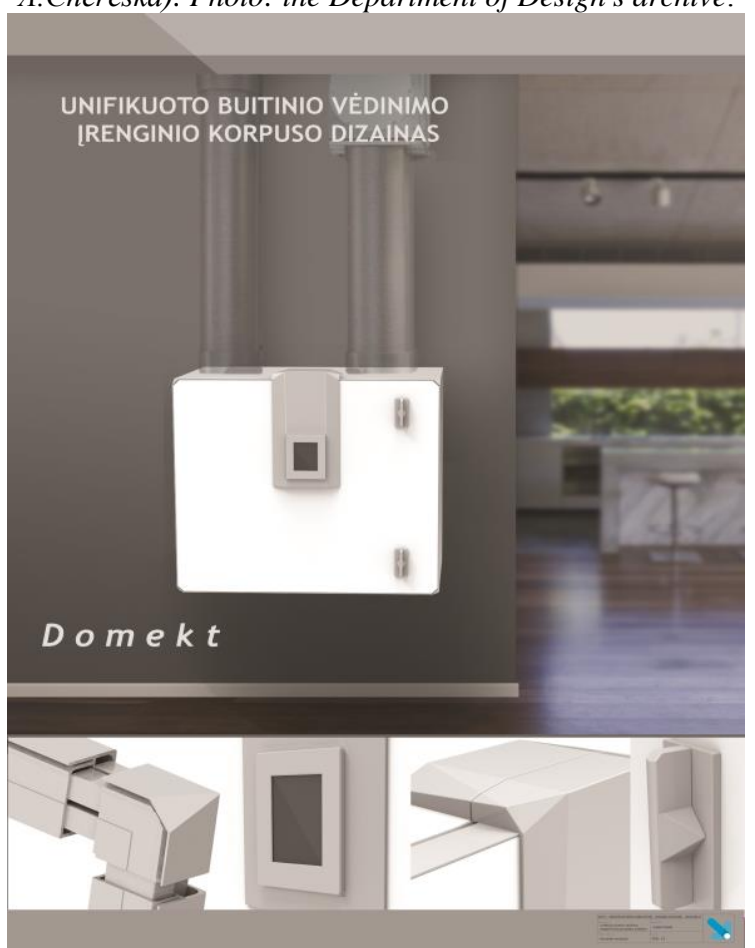

Fig. 3. A. Tylaite Bachelor's final work using the PBSL method. 'Design of the body of the compact heating, ventilation and air conditioning system. 2018' (head-Lect. D. Andziulis)

Photo: the Department of Design's archive. 
Similarly, the other design graduate student Aukse Tylaite, in 2018, solved the same task. For the same company, this time the design of the control panel for smaller heating and ventilation systems. The project, titled Domekt, successfully implemented another ambitious goal - to create aesthetic exterior of the stationary heating and ventilation device using modular mounting details (Fig. 3). Designed metal sheet panels, frames, and handles for the device greatly simplify and speeds up the production and assembly of such a product. And most importantly - maintaining a high functional and aesthetical level. The basis for these two examples will be the application of the PBSL method, involving both the process and the client. However, in this case, there is a prerequisite: the customer must contribute in the process to technical information, consultation, and the use of production equipment in the form of prototype production. Only through the development of a mutually productive partnership, the PBSL method can produce the best results.

In some cases academic partnership by PBSL method could be developed between various types of partners. Not necessary with private companies, but also with public research institutions. Graduate student of VGTU Design department Ieva Strelkauskaite created project of Automatic fish feeder (Fig. 4). During the design process student collaborated with Lithuania fishery department at Lithuania Agricultural ministry senior specialist Rolandas Morkūnas. As a final result student designed an ergonomic, digitally programmable fish feed disperser. Exterior design was inspired by contemporary architectural and environmental trends. Purpose of the designed object - to ensure fish feeding process for small outdoor ponds or recirculating aquaculture systems. Researching the problematic territory aspects of a part of Vilnius city, the members of the "Žirmūnai Community" as partners of the Institute of Architecture participated not only in the formulation of tasks but also in the assessment of solutions. In this way, the ideas of student projects developed at the Institute gradually became the basis of real decisions. Investigating qualitative parameters of the 1940-1990 formed Žirmūnai residential area's territory development and material environment, it has been determined that this living space of the type of free planning, and in particular its northern part, has a building density of $60 \%$ and a building intensity of 1.2 . According to the data of the respondents in the surveys conducted in 2013-2016 ( $\mathrm{n}=375)$, green spaces, urban composition, building form quality, the forms of material environment were partially satisfactory at $40,8 \%, 18,3 \%$ were unsatisfactory and $39.4 \%$ of the building areas were evaluated positively.

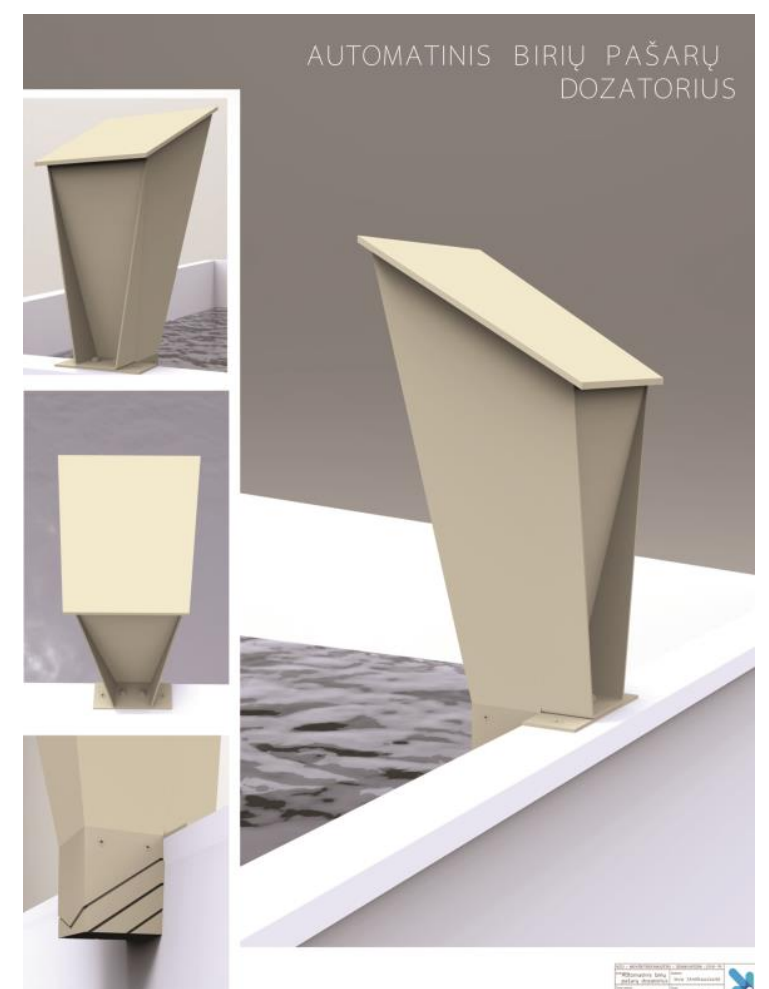

Fig. 4. I. Strelkauskaite, Bachelor's final work using the PBSL method. "Automaticfish feeder", 2018 (head-Assoc. prof. L. Krūgelis)

Photo: the Department of Design's archive.

However, positive respondents judged the residential area's geographical convenience of the location of the district's urban space advantage, communication with the centre and the protected areas (Verkiai regional parks) as an advantage, but not the material environment and the quality of residential and public spaces (in the case study, the material environment has not changed substantially since the Soviet times - author's note.) Thus, in this case, the material environment of the residential area was positively evaluated by just $20,4 \%$ of the Žirmūnai residents [18]. This allowed students to form the concept of Landscape Architecture of Žirmūnai northern area "Neris Valley Žirmūnai Park" $[25 ; 26]$. Today, on the initiative of the Žirmūnai community, this project is developed with professionals at the level of technical projects and real solutions.

Implementation of another cooperation project conducted between the VGTU Design Department and the Lithuanian Road Administration (LKAD) under the Ministry of Transport and Communications was determined by the paradigm of the Industrial Product Design study program that the newly created objects of the material environment must improve the quality of the environment, have a clear purpose and function, create and reflect the uniqueness of the site, which received the support of the Lithuanian Road Administration's 


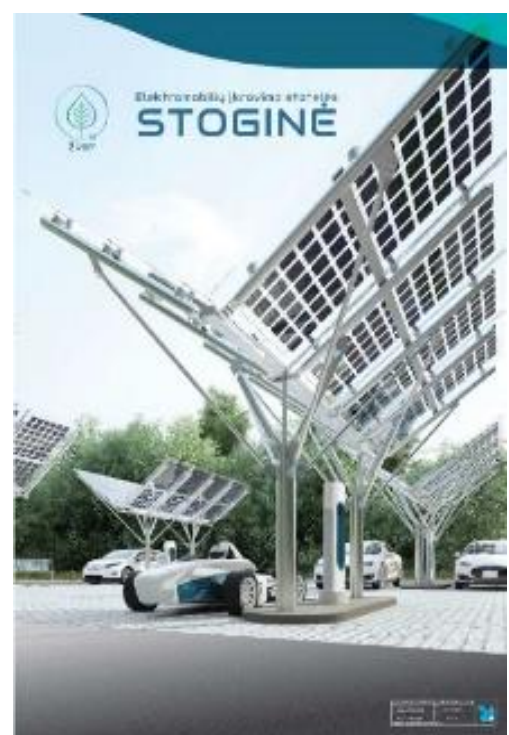

Fig. 5. 2017 J. Plockytè's bachelor's degree project, applying the PBSL method. "Electromobility Charging Station". 2017

(supervisor Dr. L. Krūgelis, consultant Dr. A. Rotman)

Source: the Department of Design's archive.

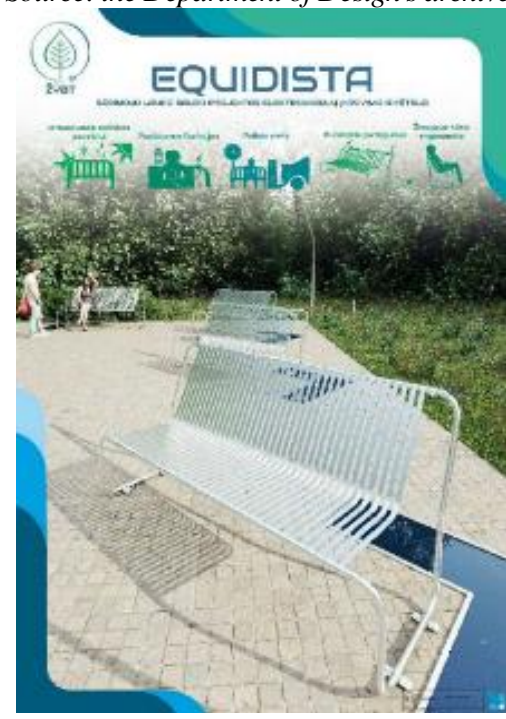

Fig. 6. 2017 V. Benešis' bachelor's degree project, using the PBSL method. "Outdoor Furniture Project". 2017 (supervisor Dr. L. Krūgelis, consultant Dr. A. Rotman) Source: the Department of Design's archive.

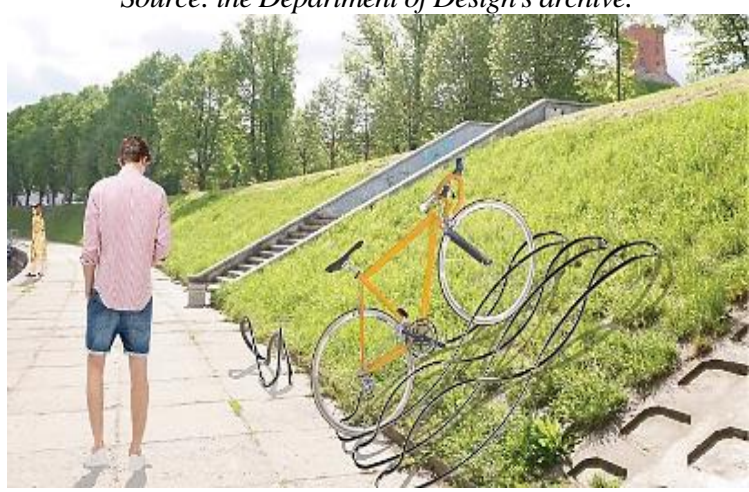

Fig. 7. 2016 Conceptual work of a third-year student (under the direction of M. Užkuraitis, Doctor Dr. A.

Rotman), project for the arrangement of Neries quays in Vilnius, using the PBSL method.

Photo: the Department of Design's archive. management. In 2016 a mutual cooperation project was developed, which led to the signing of the VGTU and LAKD Partnership Agreement. VGTU Industrial Product Design second, third and fourth year students' involvement in solving specific problems, resulted in approximately 50 student road infrastructure object design solutions (Fig. 5; Fig. 6).

In assessing the experience of this process, it has been observed that students feel motivated by creating design objects that brings some technological and aesthetical advances to the surrounding environment. This is reflected not only in the desire to follow the good practices of the Western countries, but also in the desire to create new, innovative environmental solutions. As a result, in academic projects, we see successful development of topics like electric vehicle charging stations and its infrastructure elements, also street lighting units, outdoor furniture or even bus stops. All of this shows that successful updating of the real issues of the material environment, it is possible to achieve high-quality results.

With the coordination of the study program committee, Professors D. Anziulis, L. Krūgelis, M. Užkuraitis with the Consultants of the Mechanical Engineering and Materials Department successfully implemented the tasks assigned to the students (formulated in the conditions of the Lithuanian Road Administration - author's note). They have developed conceptual variants of several engineering infrastructure objects. The application of the PBSL method has led to the development of functional and aesthetic ideas, which commune with a particular landscape and meet the current social comfort and quality expectations. The decision was made to make the roadside islands of public areas of the suburban roads would gain distinctive features, not only to be visible, but also comfortable to use. Students exhibited prototype objects created at the exhibition, opened in the premises of LKAD. Looking in general at the PBSL methodology, similar collaborative initiatives could achieve even better results if the actual implementation of design prototypes in the real area was intensified and the data on the functionality of the object were collected from real users. Undoubtedly, such an event requires a greater involvement of the client in the implementation of the process.

In the course of 2015-2016, another very important city of Vilnius Municipality and VGTU partnership project, was associated with the upgrade of the Neris quay in Vilnius. To solve the project's problems, the municipality invited VGTU Department of Design students to create ideas for the recreational use of Neris quay public areas and engineering infrastructure objects (Fig. 7). 
For some students, this was the first challenge of practical experience, therefore, Vilnius city Mayor Remigijus Šimašius's wishes were very important to them. "First of all, Neris is a very important city's artery, which the city begins to habituate with. The great reconstruction of the quay, renovation works are already visible to residents and guests of the city, but these works are just the beginning. No less important projects are still waiting - these are elements of small architectural design that give the quay a distinctive face, which is why I am very pleased that young people are joining into this "face" search", - said the head of the capital. Thus, the students created concepts for designing modern, contemporary, tailor-made, environmentally-friendly, and practical objects. The results reflect the involvement of students, their enthusiasm and their willingness to contribute to the restoration of the Neris quay, the creation of distinctive and interesting public spaces of the capital and the formation of a better quality of life for the citizens. If this real-life design and development process continues to include local manufacturers and daily users, even more advanced technical and engineering skills could be achieved. And at the same time, many created prototypes or conceptual projects could become a real object of the city's environment. Students have already mastered the experience and project ideas in their final works.

In another 2017 international cooperation INTERG-V project "Raising Competitiveness at the PL_LT Border Through the Development of Clustering Services", the Department of Design third-year students received a particularly favorable attention [27]. The aim of the project was related to the development of innovations and the enhancement of the competitiveness of the border region in relation to the development of contemporary applied material environment design objects that students enthusiastically implemented. Therefore, the use of design as a creative tool to achieve these goals was timely. The Industrial Design students had a special task on the project - to prepare the design concept of a material environment design object in a specific area of Alytus city with the possibility to produce a prototype M1:1 and to implement it in a mass production, which proved to be substantially done. The idea itself has successfully expanded to Vilnius city public spaces as well. A successful discourse has taken place with employees of the National Art Gallery (Fig. 8).

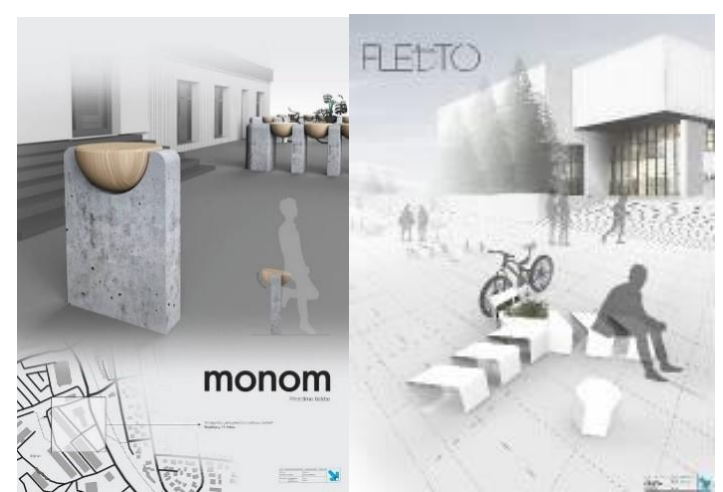

Fig. 8. 2017 INTERG project "Raising Competitiveness at the Border of PL-LT Through the Development of Clustering Services", using the PBSL method, was prepared by J. Judžentis, third-year student of the Design

Department; D. Česokaitè (supervisors: Associate Professor J. Jakaitis,

Lecturer M. Užkuraitis, Consultant Dr. A. Rotmanas) Source: the Department of Design's archive.

Integrating the various fields of activity: education (project participants Vilnius Gediminas Technical University, Bialystok University of Technology - author's note), business, social partners, production and services sector competences, skills and experience of natural and legal persons, competences of vocational education institutions, developed in the project partnership network. A cooperation agreement signed by 12 partners for a five-year period illustrates the success of this phenomenon. The project was aimed at increasing added value and increasing its competitive advantage by further promoting crosssectoral integration of increasingly widespread design solutions. Aesthetic, functional and meaningful object - is the result of design thinking, that manifests itself in innovative solutions. Thus, the achievement of Problem-Based Service-Learning method - to bring the education conditions closer to the solving of the real problems - has fully proved to be functional. The application of the method has revealed that in the process of co-operation, the partners experience mutual benefits oriented to meaningful learning. For example, with the continuation of the partnership, an exhibition of conceptual material environment design objects created in the framework if the INTEREG V project by the third-year Industrial Design students of Vilnius Gedimino Technical University opened at the Alytus City Municipality. A meeting with Alytus Municipal Council members and business representatives was held in order to reach a further partnership. During this project, the experience of the implemented project regarding the improvement of the quality of education was discussed (Fig. 9). 


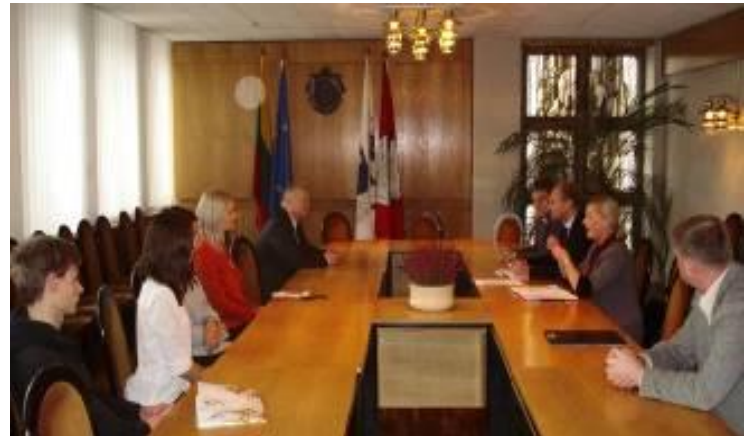

Fig. 9. During the implementation of the INTEREF V project, an analysis of Alytus City material environment quality and needs were assessed: a problematic discussion between the representative of VGTU and Alytus City Mayor V. Grigaravičius.

Photo: the Department of Design's archive.

In regards of the practical implementation of the PBSL method, the choice of appropriate technological tools becomes a crucial factor. For example, an integral part of this process is the deployment of computer simulation programs and their management skills. For this purpose, one of the most advanced engineering computers' design programs - Solidworks was introduced at the Industrial design study program of VGTU Design Department five years ago. The teaching of Solidworks basic skills have been started for the very first year students and continued to more advanced level. In this way, during the three semesters of studies, students form the necessary skills not only to design complex products in the virtual space, but also to represent them in aesthetical way. Moreover, in order to ensure the future quality of the product, Solidworks allows the product to be simulated in terms of structural strength, thermal management and etc. This is especially useful when delivering design ideas to project partners. In the course of this practice, it has been observed that good engineering design skills are highly valued in the labor market, and for students this gives motivation and confidence in the creative process.

Experience has shown that using the PBSL method and using more efficient technological process solutions, as well as combining the principles of design thinking, integrity and interdimensionality, it is possible to create a better environment for learning, oriented towards practical solutions, and more diverse (inclusive design - author's note) of the material environment design options.

\section{Conclusions}

In the conditions of the consumer society in the global world, it is necessary to apply measures promoting creativity. Innovative teaching methods, based on partnership and real problem solving, which create preconditions for more effective design use in shaping the aesthetics, purpose or function of a material environment in public or private spaces.

Urban areas, and especially public spaces, have no other purpose than those intended to serve people's social, cultural, or economic needs. Therefore, teaching / learning in unconventional, partnership-based ways is important for the harmonious coexistence of the material environment and people in urban areas.

Studies have revealed that Problem-Based Service-Learning (PBSL) is particularly useful for addressing real issues. The more problematic the situation is, the higher the probability of creativity and motivation in the education process. Consequently, the PBSL methodology based on knowledge and skills through solving real problems in industrial product design studies is highly motivating the students. Through real research cases, it can be argued that this can be used as a teaching / learning strategy to address contextualized, real issues of harmonization of design in the material environment. Problem-solving resources can be focused not only on optimized management and marketing tasks, but also on strategic planning for the harmonization of the material environment. This is nothing more than an integrated, interdisciplinary teaching / learning direction and a design policy making tool. PBSL method, used to fill the gaps of traditional teaching/learning, is not only focused on the student, but also focused on the producer and the society, i.e. the formation of an inclusive design tradition. Thus, the partnership between the study subjects, the producer and the public is a viable tool for the development of inclusive design.

The achievement of the Problem-Based ServiceLearning method, to bring the teaching / learning conditions closer to solving actual problems, fully proved its implementation in the particular VGTU Industrial Product Design study program. The application of the method has revealed that in the process of co-operation, the partners experience mutual benefits oriented to meaningful learning. It is concluded that the PBSL method is an effective and meaningful tool for teaching / learning and designing, developing the material environment. 


\section{References}

1. Erlich T. Civic responsibility and higher education. Phoenix, AZ: Orynx Press. 2000.

2. Valstybès pažangos strategija „Lietuva 2030“[online 19.05.2017]. https://www.lietuva2030.1t/lt

3. Daujotytè V. Kūrybingumas ir kūrybiškumo atpažinimas. Mokslo Lietuva, 2010, Vol. 3(425).

4. Minkevičius, J. Lietuvos architektūros istorija. Vilnius: Mokslas, 1988.

5. Rogers, C. On Becoming a Person. Boston, MA: Houghton Mifflin, 1961.

6. Ramsden, P. Kaip mokyti aukštojoje mokykloje. Vilnius: Aidai, 2000.

7. Lobell, J. Between Silence and Light: Spirit in the Architecture of Louis I. Kahn. Boston; London: Shambhala Publications, Inc., 2000. 120 p.

8. Lenkauskaitė, J. Probleminio mokymosi taikymas aukštajame moksle, realizuojant besimokantiesiems prasmingas studijas. Profesinés studijos: teorija ir praktika, 2010, Vol. 6, p. 107-113.

9. Jakaitis, J. The PBT/LM of material environment in the urban spaces. International journal of educational sciences. Gurgaon: Kamla-Raj Enterprises. 2016, Vol. 15(1-2), p. 214-224.

10. European Comission. Dizaino Komisija kuriant augančią ir klestinančią ekonomiką. Europos pramoninio dizaino srities tarybos ataskaita ir rekomendacijos. Europos dizaino inovaciju iniciatyva. 2012, p. 8

11. Lefebvre, H. Writings on cities. Malden, MA: Blackwell Publishers Ltd, 1996.

12. World Intellectual Property Indicators [online 11.01.2018]. http://www.wipo.int/edocs/pubdocs/en/wipo_ pub_941_2015.pdf

13. Europos Komisija. 2009. Tarnybų darbinis dokumentas „Dizainas - i vartotojus orientuotų inovacijų variklis“ (SEC (2009)501 galutinis)

14. Patvirtinta LRV 2010 m. vasario 17 d. nutarimu Nr. 163, Studijos [online 14.01.2018]. http://www.vgtu.lt/architekturosfakultetas/padaliniai/dizaino-katedra/studijos/52060

15. Global Innovation Index 2017. IBGE, 2016; OECD, Innovation in Science, Technology and Industry database, [online 11.02.2017] http://www.oecd.org/sti/inno/

16. Whicher, A. Lithuanian Design Policy Workshop 3 May 2016 Report. [online 11.07.2017] $\mathrm{http} / / /$ www.designforeurope.eu/sites/default/files/asset/document/LT\%20Design\%20Policy\%20Report\%2003.05.16.pdf

17. Maslow, A. H. Motivation and personality. New York: Harper\&Row, 1970.

18. Fyrenius, A., Bergdahl, B., Silen, C. Lectures in problem-based learning. Why, when and how? An example of interactive lecturing that stimulates meaningful learning. Medical teacher, 2005, Vol. 27, p. 61-65.

19. Šiukščius, G. Dizainas: menas, mokslas, technika. Vilnius: Vilniaus dailès akademijos leidykla, 2005.

20. Kliukas, R., Martinkutè-Kaulienė, R., Mažeika, D., Jakaitis J., Jučiūtė E., 2015. Universitetas atveria naujas studijų galimybes. Sapere Aude. Vilnius: VGTU, 2015, No. 2(10), p. 10-17.

21. Burinskienè, M., Jakaitis, J. et. al. Europos Sajungos ir Lietuvos Respublikos Lèšomis Finansuojamas Projektas „Darniosios gyvenamosios aplinkos studiju srities programu atnaujinimas, inovatyviu mokymosi metodu pagalba stiprinant tarpdalykines sasajas ir diegiant darniosios raidos samprata“", 2011. Sutarties Nr. VP1-2.2-ŠMM-07-K-01048.

22. Jakaitis, J. Miestu inžinerijos studiju programos (612H27001) Kompleksinio projekto 1 (Teritorijos sutvarkymo (modulio kodas APMSB11608)) rengimo metodine mokymo priemoné: mokomoji knyga. Vilnius: Miestų statybos katedra. 59 p. [online 11.07.2014]. http://moodle.vgtu.lt/course/info.php?id=166.

23. Jakaitis, J. Miesto erdvinio formavimo dalyviu diskursas šiuolaikinès demokratijos sąlygomis. Vilnius: Technika, 2013.

24. Buidovaitė K. Komfortiškas klimatas - vienu ịrenginiu [online 11.01.2018]. http://sa.lt/ru/komfortiskas-klimatas-vienuirenginiu/

25. Žirmūnai žydintys sodai [online 19.07.2017]. http://ar.vgtu.lt/architekturos-fakultetas/padaliniai/architekturos institutas/mokslas/52111\#tab-projektai

26. Jakaitis, J.; Linartas, D.; Džiugytė, T.; Gruodytė, B.; Zacharevič, T. „Žirmūnai - žydintys sodai“", Neries slènio Žirmünu parko koncepcija [online 19.05.2015]. http://ar.vgtu.lt/fakultetai/padaliniai/architekturos-institutas/kitainformacija/52114

27. Jakaitis, J. Aptartos "INTERREG V" projekto plètros galimybès [online 31.01.2018]. http://ar.vgtu.lt/fakultetai/ padaliniai/dizaino-katedra/kita-informacija/52066\#288737

\section{INFORMATION ABOUT THE AUTHORS:}

Jonas Jakaitis - PhD of Humanities, architect, professor of VGTU. Research interests: Urban planning and design, sustainable living and living environment, landscape architecture, urban planning regulation and the development of democracy, urban ethnoculture, public-private partnership and research into the participation of the public in the process of urban architectural development, research on the interaction of urban architectural environment and society. E-mail: jonas.jakaitis@vgtu.lt

Linas Krūgelis - PhD of Humanities, Assoc. Profesor at Vilnius Gediminas Technical University, Department of Design; e-mail: Linnarri@yahoo.com Research. Interests: Contemporary architecture, Industrial design, CAD engineering.

Kopsavilkums. Rakstā pētītas industriālā produktu dizaina mācību procesa īpatnības Viļnas Gediminas Tehniskajā universitātē. Autora skatījums ir attīstījies no konceptuālas idejas līdz prototipam un ir pamatā diskusijām par jautājumu: cik labi dizaina izglītība spēj sagatavot studentus reālām praktiskajām darbībām? Faktiski, tiek pētīts vēsturiski dominējošais dizaina izglītības modelis, kas balstās uz profesionālām prasmēm bez reālas praktiskas adaptācijas. 